\title{
Manajemen Krisis Public Relations PT. X Kota Pekanbaru pada Pengunduran Haji dan Umrah di Era Pandemi Covid-19
}

\section{Laranty Irabella*, Maman Chatamallah}

Prodi Public Relation, Fakultas Ilmu Komunikasi, Universitas Islam Bandung, Indonesia.

*larantyirabella@gmail.com, maman.chatamallah@unisba.ac.id

\begin{abstract}
This research is entitled "Public Relations Crisis Management of PT. X (Case Study of Public Relations Crisis Management of PT. X Pekanbaru City on Hajj and Umrah Withdrawals in the Era of the Covid-19 Pandemic)". This study aims to determine the stages of PT X's crisis management in Pekanbaru city, the obstacles and support they received, as well as the reasons for PT X's use of a crisis plan in the company's crisis management. Data collection is done by interview, observation, documentation, and literature study. The validity of the data was tested using a triangulation test. The results of this study indicate that PT X has carried out 4 stages of a crisis plan well, the four stages are planning, communication during a crisis, responding in a crisis, and recovery and evaluation.
\end{abstract}

Keywords: Public Relations, Crisis, Crisis Management.

Abstrak. Penelitian ini berjudul "Manajemen Krisis Public Relations PT. X (Studi Kasus Manajemen Krisis Public Relations PT. X Kota Pekanbaru pada Pengunduran Haji dan Umrah di Era Pandemi Covid-19)". Penelitian ini bertujuan untuk mengetahui tahapan manajemen krisis PT X kota Pekanbaru, hambatan dan dukungan yang di dapatkan, serta alasan PT X menggunakan crisis plan dalam manajemen krisis perusahaan. Pengumpulan data dilakukan dengan wawancara, observasi, dokumentasi, dan studi kepustakaan. Uji keabsahan data dilakukan menggunakan uji triangulasi. Hasil penelitian ini menunjukkan bahwa PT X melakukan 4 tahapan crisis plan dengan baik, keempat tahapan tersebut ialah planning, communication during a crisis, responding in a crisis, dan recovery and evaluation.

Kata Kunci: Hubungan Masyarakat, Krisis, Manajemen Krisis. 


\section{A. Pendahuluan}

Dalam dunia komunikasi, kita dituntut untuk berinteraksi guna mencapai tujuan dan keselarasan makna, yang disebut dengan komunikasi adalah terdapat pesan yang disampaikan dari seorang komunikator kepada komunikan. Menanggapi hal tersebut tentunya komunikasi selalu kita lakukan dalam kehidupan sosial, yakni bersosialisasi terhadap sesama. Kita hidup di dunia ini tentunya tidak bisa tanpa bantuan orang lain, karena berkat interaksi tersebut itu terjadilah roda kehidupan sebagaimana menjadi makhluk sosial, kita mempunyai ayah dan ibu, adik dan kakak, dan sebagainya. Komponen itu semua biasa kita sebut dengan keluarga, keluarga merupakan komponen penting bagi kita untuk bertukar pikiran, pembelajaran awal yang didapat pun berasal dari sana. Istilah keluarga sudah menjadi umum kita dengar, karena keluarga merupakan tempat awal kita bernaung, diberi kehidupan dari berbagai sektor seperti agama, pendidikan, sopan santun, ekonomi, dan sebagainya. Semua indikator tidak luput dari lingkup komunikasi yang memadai, karena keadaan seseorang yang jarang berkomunikasi atau berinteraksi berbeda jauh dengan yang sering melakukannya. Komunikasi yang kita lakukan di zaman serba canggih ini memungkinkan kita untuk melakukan komunikasi jarak jauh, tidak perlu bertatap muka, cukup menggunakan handphone atau telepone genggam. Berita - berita yang ada mau itu berasal dalam negeri bahkan sampai luar negeri pun dapat kita ketahui karena kemajuan teknologi, salah satunya adalah berita tentang pandemi Covid-19 yang melanda beberapa negara di dunia, berawal dari kota Wuhan, Tiongkok hingga merambat ke tanah air.

Pada awal Maret 2020 lalu, Presiden Indonesia yakni Joko Widodo mengumumkan bahwa terdapat warga Indonesia yang terkena Virus Covid-19 ini, bermula dikarenakan orang Jepang yang positif berkunjung ke Indonesia dan setelah di telusuri terdapat dua WNI (warga negara Indonesia) yang terinfeksi akan virus ini. Coronavirus adalah suatu kelompok virus yang dapat menyebabkan penyakit pada hewan dan manusia. Beberapa jenis virus ini dapay menyebabkan infeksi saluran pernafasan. Terhitung sejak maret hingga oktober kasus positif Covid-19 ini terus bertambah, dan akan terus seperti itu sebelum vaksin di edarkan ke masyarakat khususnya di seluruh dunia yang mendapat penyebaran Covid-19 ini. Di tahun 2020, menjadi tahun yang sangat bersejarah, karena banyak sekali kejadian - kejadian yang terjadi, khususnya negara Indonesia yang mendapatkan dampak ekonomi, agama, dan sebagainya diakibatkan oleh pandemi Covid-19 ini. Banyak perusahaan ternama yang terpaksa bangkrut akibat minimnya pendapatan, pemutusan hubungan kerja (PHK) pun di lakukan karena tidak mampu untuk membayar gaji maupun tunjangannya. Jika perusahaan bisa mengalami dampak buruk akibat pandemi ini, tentu saja masyarakat kecil yang lebih mendapatkan dampak negatif dari pandemi ini.

Salah satu perusahaan yang mendapatkan dampak pandemi Covid-19 adalah PT X, PT $\mathrm{X}$ adalah sebuah perusahaan di bidang jasa Tour \& Travel Haji dan Umroh, yang berdiri di Kota Pekanbaru. Tahun 2020 menjadi pukulan telak bagi para calon jemaah haji dan umroh, dikarenakan pandemi Covid-19, karena kita telah mempersiapkan segala sesuatu untuk melaksanakan niat suci kebaitullah dan juga merupakan rukun islam yang kelima. Pelaksanaan haji biasanya akan terus dilakukan setiap bulan dzulhijjah, tetapi dikarenakan adanya konflik bersenjata dan wabah penyakit, sehingga untuk tahun 2020 ini haji tidak dilaksanakan atau dibatalkan. Dikutip dari The New Arab yang mengambil dari Saudi King Abdulaziz Foundation for Research and Archives, telah terjadi sekitar 40 kali pembatalan haji. Pendiri PT X yakni bapak Irma Romi Anto diundang oleh riau televisi untuk membahas tentang pengunduran keberangkatan haji dan umroh khususnya di kota pekanbaru dan seluruh masyarakat provinsi Riau yang mempercayakan PT X dalam melakukan perjalanan ke tanah suci. Pemimpin berperan penting dalam berkomunikasi dengan para anggota yang dipimpinnya.

Sebelumnya peniadaan atau tidak adanya ibadah haji tidak hanya terjadi di tahun pandemi covid-19 ini. Karena ada beberapa faktor karena wabah penyakit dan juga peperangan, seperti tahun 865 terjadi pembantaian di bukit arafah, di tahun 1837-1858 ibadah haji ditiadakan sebanyak tiga kali dikarena berbagai wabah yang menyerang di mekah seperti wabah kolera. Peristiwa yang terjadi murni keadaan spontanitas, karena kita dihadapkan dengan situasi yang menyerang seluruh negara di muka bumi ini, hal ini diharapkan agar kita mampu mengambil solusi dan antisipasi dalam menghadapi keadaan yang berdampak pada kehidupan kita terutama. 
Krisis merupakan keadaan genting yang terjadi secara spontanitas atau tiba-tiba, yang dapat menimbulkan dampak positif dan juga negatif khususnya institusi atau perusahaan. Istilah yang sering kita dengar adalah manajemen krisis, istilah ini merupakan keadaan sebuah perusahaan dalam menghadapi situasi genting untuk kemajuan organisasinya, dimulai dari tahap persiapan, pelaksanaa, bahkan evaluasi. Peran Public Relations atau PR atau istilah terkenalnya adalah humas, memegang peran penting dalam hal ini, karena seorang PR merupakan jalur penghubung antara perusahaan ke masyarakat, dan masyarakat ke perusahaan, seorang PR harus dapat menciptakan kepercayaan dan dukungan penuh terhadap perusahaannya, dalam hal ini seorang PR harus terus berkomunikasi kepada para calon jemaah mereka, agar dapat mengetahui kemauan dalam menghadapi pengunduran ini, setiap umat muslim tentu tidak melepaskan kesempatan untuk menginjakkan kaki di tanah suci yang merupakan tujuan serta cita-cita dalam beribadah kepada Allah, umur dan ajal kita tidak dapat memastikan. PT X merupakan sebuah perusahaan yang terkena dampak Covid-19, dengan alasan utama atas pemikiran tersebut penulis ingin mengadakan sebuah penelitan tentang Manajemen Krisis Public Relations PT X dalam menghadapi pandemi ini dengan judul "Manajemen Krisis Public Relations PT. X Kota Pekanbaru pada Pengunduran Haji dan Umrah di Era Pandemi Covid-19"

Berdasarmkan latar belakang yang telah diuraikan, maka perumusan masalah dalam penelitian ini sebagai berikut:

1. Bagaimana Tahapan - Tahapan Manajemen Krisis yang di lakukan Public Relations PT X Kota Pekanbaru pada Pengunduran Haji dan Umroh di Era Pandemi Covid-19?

2. Bagaimana Dukungan dan Hambatan dalam Manajemen Krisis Public Relations PT X Kota Pekanbaru pada Pengunduran Haji dan Umroh di Era Pandemi Covid-19?

3. Mengapa PT X Melakukan Tahapan Crisis Plan dalam Manajemen Krisis Public Relations pada Penguduran Haji dan Umroh di Era Pandemi Covid-19?

\section{B. Metodologi Penelitian}

Metode dalam penelitian ini menggunakan metode kualitatif dengan pendekatan studi kasus. Dan studi kasus dalam penelitian ini termasuk kedalam kasus tunggal. Sebuah studi kasus penelitian bertujuan untuk menguji pertanyaan dan masalah penelitian, yang tidak dapat dipisahkan antara fenomena dan konteks di mana fenomena itu terjadi. (dalam Prihatsani, Suryanto, dan Hendriani 2018:128). Kemudian dalam penelitian ini pengumpulan data menggunakan studi kepustakaan untuk mendukung penelitian, observasi dengan mendatangi perusahaan secara langsung, dokumentasi berupa keadaan perusahaan di saat pandemi dan wawancara langsung kepada direktur utama bapak Romi, kepala humas ibu Angel, dan calon jemaah yang batal berangkat yaitu bapak Mahmud.

\section{Hasil Penelitian dan Pembahasan}

\section{Tahap Planning}

1. Membentuk sebuah tim yang terdiri dari 5 orang dan tentu yang menjadi ketua tim adalah bu angel.

2. Memberi pembekalan berupa informasi dan update terkini mengenai virus corona yang menyerang dunia saat ini. Serta informasi mengenai keberangkatan dan dana yang sudah di bayarkan.

3. Menjadi narahubung perusahaan kepada para publiknya.

4. Menerima kritik dan saran dari publik untuk di sampaikan kepada perusahaan.

Tahap Communication During in A Crisis

1. Melayani publik atau calon jemaah mengenai pembatalan umroh.

2. Memberi alasan dan bukti jelas mengenai aturan pembatalan penerbangan oleh pemerintah Arab Saudi, tidak hanya berlaku bagi negara Indonesia, tetapi juga negara negara lain mengenai hal tersebut.

3. Memaparkan mengenai rincian biaya yang sudah di bayarkan kepada pihak hotel, tiket pesawat, dan visa yang mana dana tersebut tidak dapat di kembalikan tetapi menunggu untuk penjadwalan kembali (reschedule).

4. Para calon jamaah PT X adalah lansia sehingga penjelasan atau komunikasi dapat 
melalui telepon saja atau whatsapp, dan jika ada yang belum jelas PT X juga melayani untuk melakukan konsultasi atau pertanyaan yang diajukan langsung ke kantor yang beralamat di Komplek Ruko Royal Platinum II Jl. Melati No. 08B Kecamatan Tampan, Kota Pekanbaru, Riau dengan tetap menjalankan prokes.

5. Pemberhentian kerja terhadap karyawan sebanyak 5 orang karena perusahaan tidak mampu memberi gaji selama pandemi, di karenakan tidak adanya pemasukan dan penerbangan umroh selama pandemi berlangsung hingga saat ini.

6. Kegiatan perusahaan selama pandemi ini selain melayani para calon jamaah, juga melayani para mahasiswa yang ingin melakukan wawancara dan kebanyakan yang melakukan wawancara tersebut adalah mahasiswa UIN Suska Riau yang mendapatkan tugas dan analisis perusahaan agen travel haji dan umroh, kajian - kajian melalui media sosial PT X guna untuk meningkatkan iman dan taqwa kepada Allah SWT.

\section{Tahap Responding in A Crisis}

Menurut Kriyanto $(2014,203)$ terdapat fungsi media massa bagi seorang public relations, yaitu:

1. Untuk mendokumentasikan dan meningkatkan publisitas media melalui press-release. Konferensi pers, mengorganisasi event - event tertentu, dan kampanye public relations.

2. Untuk memahami publik dan persepsinya terhadap produk atau layanan yang telah dilakukan public relations.

3. Untuk memahami lingkungan sosial dan industri tempat organisasi berada.

4. Untuk mengevaluasi, meriset dan menganalisis kesempatan atau peluang - peluang dan berbagai kecenderungan (trends) di masyarakat.

5. Untuk menganalisis efektivitas perencanaan yang dilakukan public relations, termasuk kegiatan pemberian sponsor (sponsorship) dan relasi dengan komunitas (community relations).

6. Untuk mendapat informasi dan bekal bagi public relations tentang cara bertindak jika isu atau krisis membesar.

\section{Tahap Evaluation}

1. Meminta maaf sebesar besarnya kepada para calon jemaah umroh yang belum bisa di berangkatkan dalam waktu yang tidak bisa di tentukan. Dan juga dana yang belum bisa kembali dan di harapkan untuk sabar menunggu jadwal ulang (reschedule) keberangkatan umroh khususnya negara Indonesia di buka kembali.

2. Menjalin silaturahmi yang tidak terputus baik melalui whatsapp grup atau bertemu secara langsung, di sini komunikasi sangat berperan besar.

3. Selalu menjaga kualitas layanan dan melakukan kajian karena cobaan besar ini benar benar datang dari yang maha kuasa. Terus bertawakal dan meminta agar dapat di berangkatkan ke tanah suci yang menjadi impian setiap muslim.

4. PT X sudah sangat berusaha dalam menghadapi krisis ini. Mungkin belum bisa menyelamatkan karyawan yang di berhentikan akan tetapi ini menjadi suatu pembelajaran di masa yang akan datang jika krisis serupa terjadi akan dapat diantisipasi dan diminimalisir pengurangan pegawai akibat keterbatasan pendapatan perusahaan akibat pandemi ini. Informan ketiga yakni bapak Mahmud sebagai narasumber ahli sudah menjabarkan bahwa tahapan-tahapan yang di lakukan oleh pak Romi dan bu Angel kepada para calon jemaah sudah sesuai dengan pernyataan yang mereka berikan di waktu wawancara sehingga peneliti dapat menyimpulkan bahwa data yang di dapat sesuai dengan uji keabsahan data yakni uji triangulasi sumber.

Hambatan yang terjadi di saat krisis adalah datang dari pihak internal, karena pemberhentian karyawan merupakan salah satu cara bagi perusahaan untuk dapat dan terus berdiri, kemudian dalam menyampaikan informasi terkini mengenai pengunduran umroh ini terdapat kendala dalam sinyal juga, karena di beberapa daerah terpencil banyak sekali yang ingin menggunakan PT X untuk perjalanan umrohnya, dan tidak semua calon jemaah memiliki kemajuan teknologi seperti handphone android. Dukungan yang di berikan tentunya antara pimpinan dan karyawan selalu mengayomi, dan untuk pemberhentian kerja bagi karyawan merupakan evaluasi yang sangat berat perusahaan lakukan demi kepentingan dan kemajuan masing - masing. Karena jika di lanjutkan pun tentu akan menjadi boomerang bagi keduanya, 
di saat karyawan terus bekerja tetapi perusahaan tidak bisa memberi gaji tentu akan ada kesenjangan di antara keduanya yang akan memperkeruh keadaan dalam krisis ini

\section{Kesimpulan}

Berdasarkan pembahasan dalam penelitian ini, peneliti menyimpulkan beberapa hasil penelitian sebagai berikut:

1. Tahapan krisis yang di lakukan memiliki empat tahap yaitu Tahap planning, Membentuk sebuah tim yang terdiri dari 5 orang dan tentu yang menjadi ketua tim adalah bu angel. Memberi pembekalan berupa informasi dan update terkini mengenai virus corona yang menyerang dunia saat ini. Serta informasi mengenai keberangkatan dan dana yang sudah di bayarkan. Menjadi narahubung perusahaan kepada para publiknya. Menerima kritik dan saran dari publik untuk di sampaikan kepada perusahaan. Tahap communications during a crisis, Melayani publik atau calon jemaah mengenai pembatalan umroh. Memberi alasan dan bukti jelas mengenai aturan pembatalan penerbangan oleh pemerintah Arab Saudi, tidak hanya berlaku bagi negara Indonesia, tetapi juga negara negara lain mengenai hal tersebut. Memaparkan mengenai rincian biaya yang sudah di bayarkan kepada pihak hotel, tiket pesawat, dan visa yang mana dana tersebut tidak dapat di kembalikan tetapi menunggu untuk penjadwalan kembali (reschedule). Para calon jamaah PT X adalah lansia sehingga penjelasan atau komunikasi dapat melalui telepon saja atau whatsapp, dan jika ada yang belum jelas PT X juga melayani untuk melakukan konsultasi atau pertanyaan yang diajukan langsung ke kantor yang beralamat di Komplek Ruko Royal Platinum II Jl. Melati No. 08B Kecamatan Tampan, Kota Pekanbaru, Riau dengan tetap menjalankan prokes. Pemberhentian kerja terhadap karyawan sebanyak 5 orang karena perusahaan tidak mampu memberi gaji selama pandemi, di karenakan tidak adanya pemasukan dan penerbangan umroh selama pandemi berlangsung hingga saat ini. Kegiatan perusahaan selama pandemi ini selain melayani para calon jamaah, juga melayani para mahasiswa yang ingin melakukan wawancara dan kebanyakan yang melakukan wawancara tersebut adalah mahasiswa UIN Suska Riau yang mendapatkan tugas dan analisis perusahaan agen travel haji dan umroh, kajian - kajian melalui media sosial PT X guna untuk meningkatkan iman dan taqwa kepada Allah SWT. Tahap responding in a crisis, pada tahapan ini PT X pernah di undang oleh televisi lokal yaitu Riau TV, dari sekian banyaknya agen travel haji dan umroh yang lebih senior, CEO PT $\mathrm{X}$ sendiri yang di undang untuk menanggapi dan memberi pandangan beliau terhadap pengunduran haji dan umroh di saat pandemi ini. Sudah 2 kali ibadah haji khususnya negara Indonesia di tiadakan yakni di tahun 2020 dan 2021 dan sudah dua kali juga CEO PT X diundang untuk membahas hal tersebut. Tahap evaluasi, kita dapat melihat bahwa PT X sudah sangat berusaha dalam menghadapi krisis ini. Mungkin belum bisa menyelamatkan karyawan yang di berhentikan akan tetapi ini menjadi suatu pembelajaran di masa yang akan datang jika krisis serupa terjadi akan dapat diantisipasi dan diminimalisir pengurangan pegawai akibat keterbatasan pendapatan perusahaan akibat pandemi ini.

2. Hambatan dan dukungan yang di dapatkan dalam manajemen krisis. Hambatan yang terjadi di saat krisis adalah datang dari pihak internal, terdapat pemberhentian karyawan sebanyak 5 orang. kemudian dalam menyampaikan informasi terkini mengenai pengunduran umroh ini terdapat kendala dalam sinyal juga karena tidak semua calon jemaah memiliki kemajuan teknologi seperti handphone android. Dukungan yang di berikan tentunya antara pimpinan dan karyawan selalu mengayomi, dan untuk pemberhentian kerja bagi karyawan merupakan evaluasi yang sangat berat perusahaan lakukan demi kepentingan dan kemajuan masing - masing.

3. Crisis Plan digunakan agar dalam Manajemen Krisis Public Relations pada Penguduran Haji dan Umroh di Era Pandemi Covid-19 yaitu Crisis plan berpotensi untuk menanggulangi bagaimana perusahaan dapat meng cover krisis yang sedang terjadi. Dengan adanya crisis plan ini maka kesulitan - kesulitan yang akan terjadi akan dapat di tanggulangi dengan maksimal. Plan harus ada dalam perusahaan PT X, begitu pun 
138 | Laranty Irabella, et al.

sebaliknya dalam kehidupan kita sebagai makhluk sosial, tentu memiliki tujuan yang harus di capai. Kesulitan yang ada akan cepat berlalu tetapi tidak bisa di biarkan begitu saja seperti air mengalir, tentu ada usaha untuk menanggulangi permasalahan tersebut, dimana kesulitan tidak akan selesai jika hanya di abaikan saja.

\section{Acknowledge}

Pertama-tama saya ingin berterima kasih kepada Allah SWT yang telah memberikan saya nikmat kesehatan sehingga penelitian ini dapat berjalan lancar dan sampai ke tahap akhir. Dan juga untuk orang tua saya yang memberikan dukungan terutama support yang luar biasa yang tiada henti di berikan sehingga menimbulkan semangat dan motivasi untuk menyelesaikan penelitian ini. Dan tidak lupa pula dosen pembimbing saya bapak Maman Chatamallah yang sudah berusaha membimbing saya dalam penyusunan penelitian ini. Dan juga terima kasih kepada para dosen khususnya Fakultas Ilmu Komunikasi Universitas Islam Bandung yang telah mendidik saya dengan beragam ilmu yang tentunya akan bermanfaat di masa mendatang.

\section{Daftar Pustaka}

[1] Kriyanto. (2014). PUBLIC RELATIONS, ISSUE \& CRISIS MANAGEMENT Pendekatan Critical Public Relations, Etnografi Krisis \& Kualitatif Edisi Kedua. Jakarta: Prenadamedia Group.

[2] Wisudani. (2008). Manajemen Krisis Public Relations PT Pertamina (Persero) Unit Pengolahan IV Cilacap (Studi Kasus tentang Manajemen Krisis oleh Hupmas PT Pertamina (Persero) UP IV Cilacap Pasca Perolehan Predikat Hitam dalam Program Audit "PROPER" Periode Tahun 2002-2003). [Skripsi]. Fakultas Ilmu Sosial dan Ilmu Politik. Universitas Airlangga Surabaya. 